\title{
Determination of Particulate Matter and Carbon Oxides in Sidestream Smoke *
}

\author{
by K. Kaneki, Y. Masuo and T. Okada \\ Central Research Institute, Japan Tobacco Inc., Yokobama, Japan
}

\section{SUMMARY}

An investigation was performed to determine optimum conditions for the generation and collection of particulate matter and carbon oxides in sidestream smoke with a cylindrical chamber of $80 \mathrm{~mm}$ internal diameter. The most adequate conditions were found to be $50 \mathrm{~cm}$ distance between the burning cone and the Cambridge filter pad and $101 / \mathrm{min}$ air flow rate through the chamber. Under these conditions, the static burn rate was virtually the same as that without the chamber and almost constant values for condensate were obtained by replicate measurements. Furthermore, the concentration of carbon monoxide delivered to a room could be estimated by this method. But, it was not possible to estimate the concentration of smoke particles in a room by use of sidestream measurements.

\section{ZUSAMMENFASSUNG}

Die optimalen Bedingungen für das Erzeugen und Sammeln der im Nebenstromrauch enthaltenen Partikelphase und Kohlenoxide wurden in einer zylindrischen Kammer mit einem inneren Durchmesser von $80 \mathrm{~mm}$ bestimmt. Als am besten geeignet erwiesen sich ein Abstand von $50 \mathrm{~cm}$ zwischen der Glutzone und dem Cambridge-Filter und eine Luftströmungsgeschwindigkeit von $101 / \mathrm{min}$. Bei diesen Versuchsbedingungen entsprach die Glimmgeschwindigkeit in der Kammer praktisch jener ohne Kammer, und die durch wiederholte Messungen erhaltenen Kondensatwerte waren fast konstant. Mit dieser Kammer ließ sich außerdem die in einen Raum abgegebene CO-Konzentration abschätzen, nicht jedoch die Konzentration von Partikeln aus dem Nebenstromrauch in einem Raum.

\footnotetext{
* Received: 28ith April 1987 - accepted: 26th April 1988.
}

\section{RESUME}

Ce travail a porté sur la détermination des conditions optimales permettant de produire et de recueillir dans une chambre cylindrique de $80 \mathrm{~mm}$ de diamètre intérieur la phase particulaire et les oxydes de carbone contenus dans le flux secondaire de fumée. C'est une distance de $50 \mathrm{~cm}$ entre le cône incandescent et le filtre Cambridge associée à un débit d'air de $10 \mathrm{l} / \mathrm{min}$ qui semble la plus adéquate. Dans ces conditions, la vitesse de combustion statique mesurée en chambre correspond à celle observée sans chambre et les valeurs obtenues pour le condensat lors de mesures répétées sont pratiquement constantes. Une chambre de ce type pourrait permettre en outre d'évaluer la concentration de CO rejeté dans une pièce. Il n'a toutefois pas été possible de déterminer la concentration dans une pièce des particules contenues dans la fumée secondaire.

\section{INTRODUCTION}

Because of the recent increase in attention to indoor air pollution by cigarette smoke, exact information has been required on the amount of particulate matter and carbon monoxide in the sidestream smoke of cigarettes. $U_{p}$ to the present, several investigators have made measurements on the amount of particulate matter and carbon monoxide in sidestream smoke with a small chamber $(1-3)$ or a cylindrical apparatus (4-6). Also, the concentration of smoke particles in a room has been measured by a piezoelectric balance mass monitor (7). 'The measured values of particulate matter in sidestream smoke per cigarette reported by these workers differ widely, e.g. $52.0 \mathrm{mg} / \mathrm{cig}$. by Neurath et al. (1) and $17.6 \mathrm{mg} / \mathrm{cig}$. by Browne et al. (6). These differences appear to arise from the particular technique or conditions used for the collection of the sidestream 
smoke, i.e. the type of chamber and the air flow rate through the chamber, rather than from the cigarette type. Therefore, an investigation was performed on the conditions for collecting smoke to provide criteria for determination of the amounts of particulate matter and carbon oxides in sidestream smoke.

\section{EXPERIMENTAL}

\section{Cigarette Samples}

Commercially available cigarettes were used for the experiment. The length (including filter) was $80 \mathrm{~mm}$ and the circumference was $25 \mathrm{~mm}$. After conditioning at $23{ }^{\circ} \mathrm{C}$ and $60 \%$ rel. hum., cigarettes were selected by weight $(0.946 \pm 0.010 \mathrm{~g})$ and pressure drop $(106 \pm$ $3 \mathrm{~mm}$ w.g.).

\section{Experimental System}

The experimental system is illustrated in Figure 1. The internal diameter of the cylindrical smoking chamber made of acrylic resin was $80 \mathrm{~mm}$. The holder with a Cambridge filter pad ( $92 \mathrm{~mm}$ diameter) was positioned at the top of the smoking chamber. The distance from the position of the cigarette to the Cambridge pad could be changed by varying the height of the chamber.
The Cambridge filter holder for collecting mainstream smoke was placed $10 \mathrm{~cm}$ from the bottom of the chamber. A cigarette was inserted horizontally into the chamber through the hole at the opposite side of the mainstream smoke holder. After ignition, the hole was closed with a stopper and the cigarette was smoked under standard smoking conditions. Sidestream smoke was collected on the Cambridge filter pad by vertical air flow which was controlled by a mass flow meter. An ice bath and a charcoal trap were used to prevent contamination of the line. The flow line was bypassed to determine the carbon oxides concentration.

\section{Smoke Analysis}

The particulate matter of main and sidestream smoke generated from five cigarettes was collected on each Cambridge filter pad. During the smoking, the temperature of the Cambridge filter pad collecting sidestream smoke was measured by a Chromel-Alumel sheath thermocouple $(0.25 \mathrm{~mm}$ outside diameter) located directly on the back of the filter pad. The amount of particulate matter collected on a filter pad was determined gravimetrically. Water and nicotine in the particulate matter were determined by gas chromatography after extraction with $n$-propanol. The gas phase of mainstream smoke collected in a sampling bag was introduced into a non-dispersive infrared $\mathrm{CO} / \mathrm{CO}_{2}$ analyzer. The mainstream smoke components of each cigarette

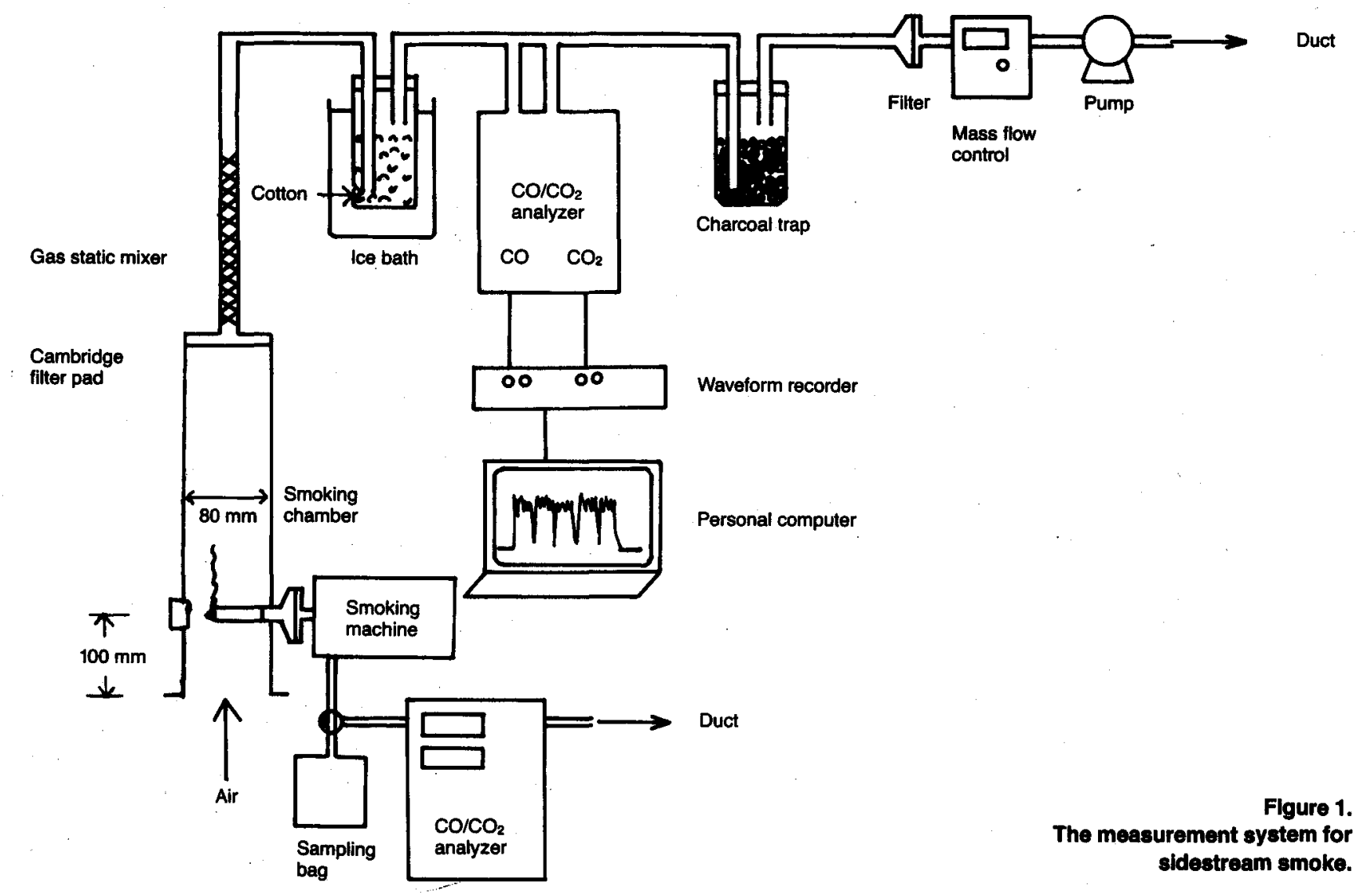


were also determined with the chamber removed. Furthermore, the change in $\mathrm{CO}$ and $\mathrm{CO}_{2}$ concentrations of sidestream smoke in the flow system was measured in a stepwise fashion by means of a second non-dispersive infrared analyzer. The output from the $\mathrm{CO} / \mathrm{CO}_{2}$ analyzer was coupled to a waveform recorder and measured at $0.5 \mathrm{~s}$ intervals. Sampling data were transmitted to an HP-86 personal computer. The time $t(\mathrm{~min})$ from the start to the end of measurement and the average concentration $\mathrm{CO}_{\mathrm{x}}(\mathrm{ppm})$ were calculated with the personal computer. The volume, $\mathrm{V}(\mathrm{ml} / \mathrm{cig}$.), of carbon oxides present in the sidestream smoke was calculated from the following equation:

$$
\mathrm{V}=\frac{\mathrm{CO}_{\mathrm{x}} \cdot 10^{3} \cdot \mathrm{L} \cdot \mathrm{t}}{10^{6} \cdot \mathrm{n}}
$$

where $\mathrm{n}$ is the number of cigarettes smoked and $\mathrm{L}$ $(1 / \mathrm{min})$ is the air flow rate. The concentrations of $\mathrm{CO}$ and $\mathrm{CO}_{2}$ were obtained by subtracting the background concentrations in the atmosphere. At least five and three replications were performed for measuring the particulate matter and carbon oxides, respectively.

\section{RESULTS AND DISCUSSION}

\section{Burn Rate}

Figure 2 shows the effect of the air flow rate through the chamber on the static burn rate. The static burn rate increased with the air flow, approaching a constant value at a flow rate of $101 / \mathrm{min}$. This value corresponded to the static burn rate of the same cigarette without the sidestream smoke chamber. Table 1 shows the dependence of smoking time on the conditions for smoke collection. The smoking time is the interval between ignition and smoking to a $30 \mathrm{~mm}$ butt length under standard conditions. The smoking time was not in-

\section{Figure 2.}

Effect of alr flow rate $\left(20^{\circ} \mathrm{C}, 1 \mathrm{~atm}\right)$ through the chamber on static burn rate.

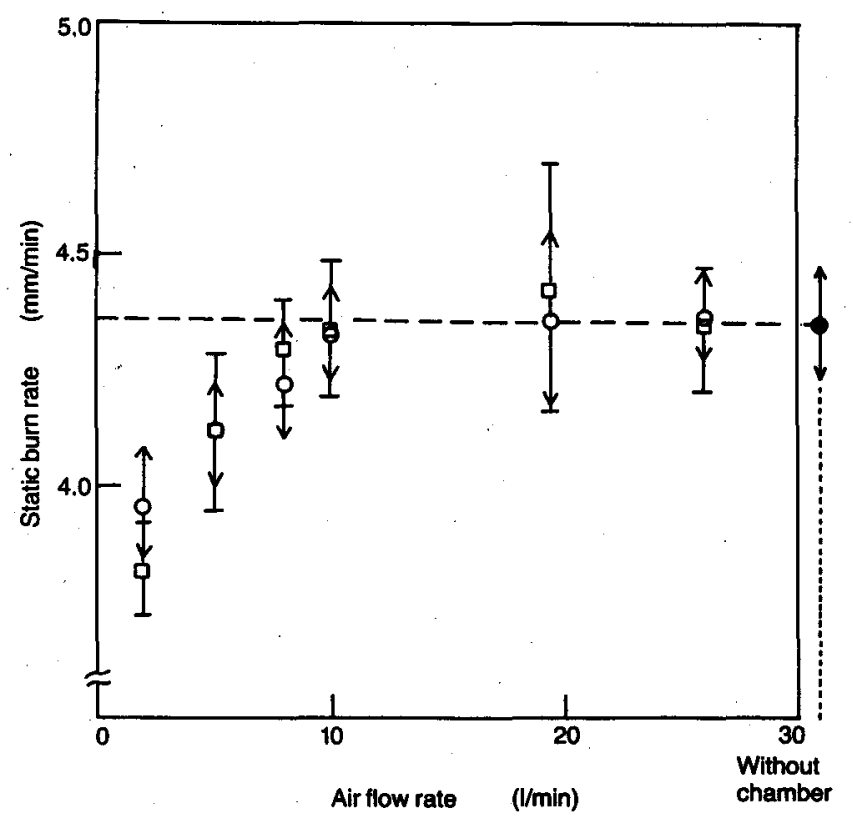

, I : standard deviation.

$0: 30 \mathrm{~cm}$ distance between burning cone and filter pad.

$\square: 50 \mathrm{~cm}$ distance between burning cone and filter pad.

fluenced by the distance between the burning cone and the filter pad.

\section{Temperature of Filter Pad \\ Collecting Sidestream Smoke}

The highest temperature of the filter pad collecting the sidestream smoke was observed to be at the position where the smoke plume directly impinged upon it. The

Table 1.

Effect of conditions for collecting sidestream smoke on the smoking time.

\begin{tabular}{|c|c|c|c|c|}
\hline \multicolumn{3}{|c|}{ Conditions } & \multicolumn{2}{|c|}{ Smoking time } \\
\hline $\begin{array}{l}\text { Air } \\
\text { flow rate } \\
(1 / \mathrm{min})\end{array}$ & $\begin{array}{l}\text { Linear velocity } \\
\text { of air } \\
\text { in chamber } \\
(\mathrm{cm} / \mathrm{s})\end{array}$ & $\begin{array}{l}\text { Distance between } \\
\text { burning cone } \\
\text { and filter pad } \\
(\mathrm{cm})\end{array}$ & $\begin{array}{l}\text { mean } \\
\text { (min) }\end{array}$ & $\begin{array}{l}\text { standard } \\
\text { deviation }\end{array}$ \\
\hline 2 & 0.66 & 50 & 513 & 23 \\
\hline 5 & 1.66 & 50 & 484 & 15 \\
\hline 8 & 2.65 & 50 & 482 & 19 \\
\hline 10 & 3.32 & 50 & 477 & 14 \\
\hline 15 & 4.97 & 50 & 479 & 9 \\
\hline 10 & 3.32 & 20 & 479 & 13 \\
\hline 10 & 3.32 & 40 & 477 & 16 \\
\hline 10 & 3.32 & 50 & 477 & 14 \\
\hline 10 & 3.32 & 60 & 470 & 28 \\
\hline Without chamber & & & 472 & 17 \\
\hline
\end{tabular}


Figure 3.

Temperature of sidestream smoke collection filter pad (air flow rate: $10 \mathrm{l} / \mathrm{min}$ ).

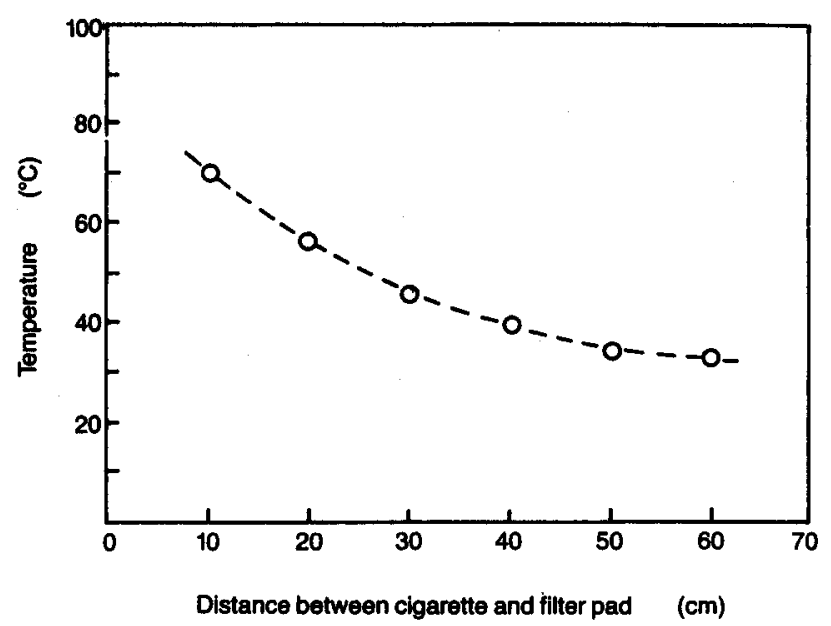

temperature was subsequently measured at this point. Figure 3 shows the temperature of the filter pad at differing positions between the burning cone and the filter pad at the chosen flow rate of $101 / \mathrm{min}$. As expected, the temperature decreased as the separation between cigarette cone and filter pad was increased.

\section{Effect of Flow Rate}

\section{on Carbon Oxides Recovery}

$\mathrm{CO}$ and $\mathrm{CO}_{2}$ standards of known concentration were released into the chamber at the same position as that of a burning cigarette under test, and the concentrations were measured at the chamber exit. Recoveries of these gases for a range of conditions are shown in Table 2. At an air flow rate of $21 / \mathrm{min}$, about $70 \%$ of the $\mathrm{CO}$ and about $80 \%$ of the $\mathrm{CO}_{2}$ were recovered at the chamber exit. This indicated that a considerable
Figure 4.

The proflle of carbon monoxide standard gas under various conditions (50 cm distance between gas inlet and filter pad).

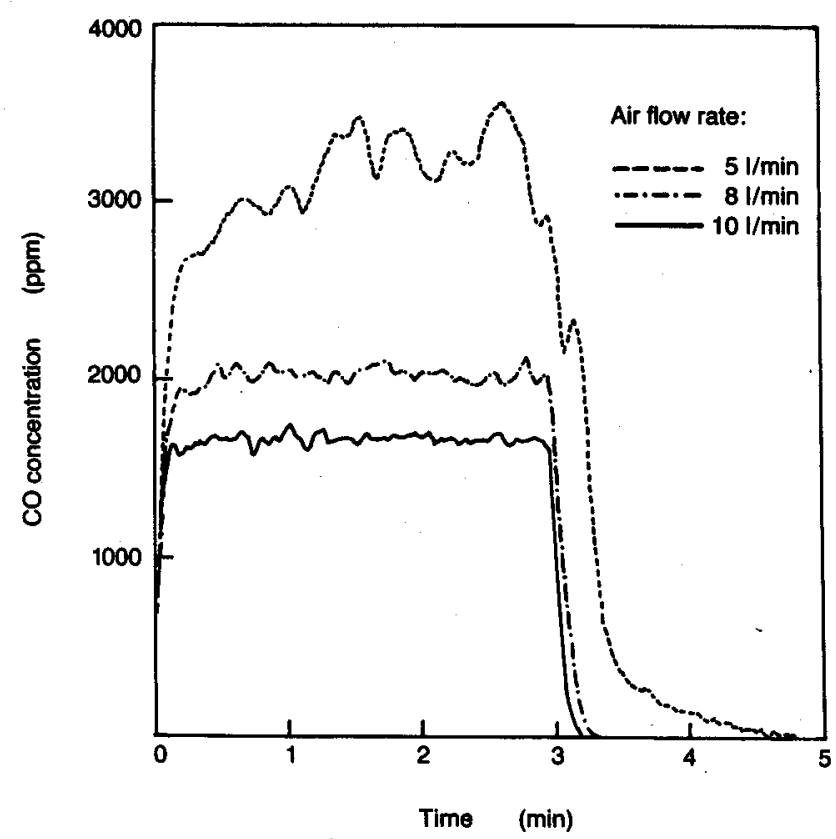

amount of both gases escapes from the bottom of the chamber. At the increased flow rate of $51 / \mathrm{min}$, however, the gases were almost completely recovered at the chamber exit. In this case it also took about twice as long for the gas concentration in the chamber to return to its normal background level. Figure 4 shows the profile for $\mathrm{CO}$ under various air flow rates. At a flow rate of $51 / \mathrm{min}$, the profile indicates the relatively poor entrainment of the $\mathrm{CO}$ and $\mathrm{CO}_{2}$ by the air flow in the chamber. A satisfactory profile for $\mathrm{CO}$ concentration was obtained under the flow rates of $81 / \mathrm{min}$ and $10 \mathrm{l} /$ min. These results (Table 2 and Figure 4) demonstrate that an air flow rate of $101 / \mathrm{min}$ is satisfactory.

Table 2.

Recoveries of the standard gases under various conditions.

\begin{tabular}{|c|c|c|c|c|c|c|}
\hline \multicolumn{3}{|c|}{ Conditions } & \multicolumn{2}{|c|}{$\mathrm{CO}$} & \multicolumn{2}{|c|}{$\mathrm{CO}_{2}$} \\
\hline $\begin{array}{c}\text { Air } \\
\text { flow rate } \\
(\mathrm{l} / \mathrm{min})\end{array}$ & $\begin{array}{l}\text { Linear velocity } \\
\text { of air } \\
\text { in chamber } \\
(\mathrm{cm} / \mathrm{s})\end{array}$ & $\begin{array}{l}\text { Distance between } \\
\text { gas inlet and } \\
\text { filter pad } \\
(\mathrm{cm})\end{array}$ & $\begin{array}{c}\text { Recovery } \\
\text { (\%) }\end{array}$ & $\begin{array}{l}\text { Measuring } \\
\text { time } \\
\text { (min) }\end{array}$ & $\begin{array}{c}\text { Recovery } \\
\text { (\%) }\end{array}$ & $\begin{array}{c}\text { Measuring } \\
\text { time } \\
\text { (min) }\end{array}$ \\
\hline 2 & 0.66 & 50 & 71.7 & 8.44 & 79.9 & 7.78 \\
\hline 5 & 1.66 & 50 & 100.9 & 4.95 & 99.9 & 5.31 \\
\hline 8 & 2.65 & 50 & 98.9 & 3.30 & 99.2 & 3.76 \\
\hline 10 & 3.32 & 50 & 99.2 & 3.23 & 97.3 & 3.51 \\
\hline 15 & 4.97 & 50 & 100.7 & 3.20 & 100.0 & 3.22 \\
\hline 10 & 3.32 & 30 & 99.2 & 3.28 & 100.1 & 3.50 \\
\hline 10 & 3.32 & 10 & 99.2 & 3.05 & 97.0 & 3.12 \\
\hline
\end{tabular}

Flow rate of standard gases: $\mathrm{CO} 16.59 \mathrm{ml} / \mathrm{min}, \mathrm{CO}_{2} 67.8 \mathrm{ml} / \mathrm{min}$, flow duration $3 \mathrm{~min}$. 
Figure 5.

The profile of sidestream smoke carbon monoxide.

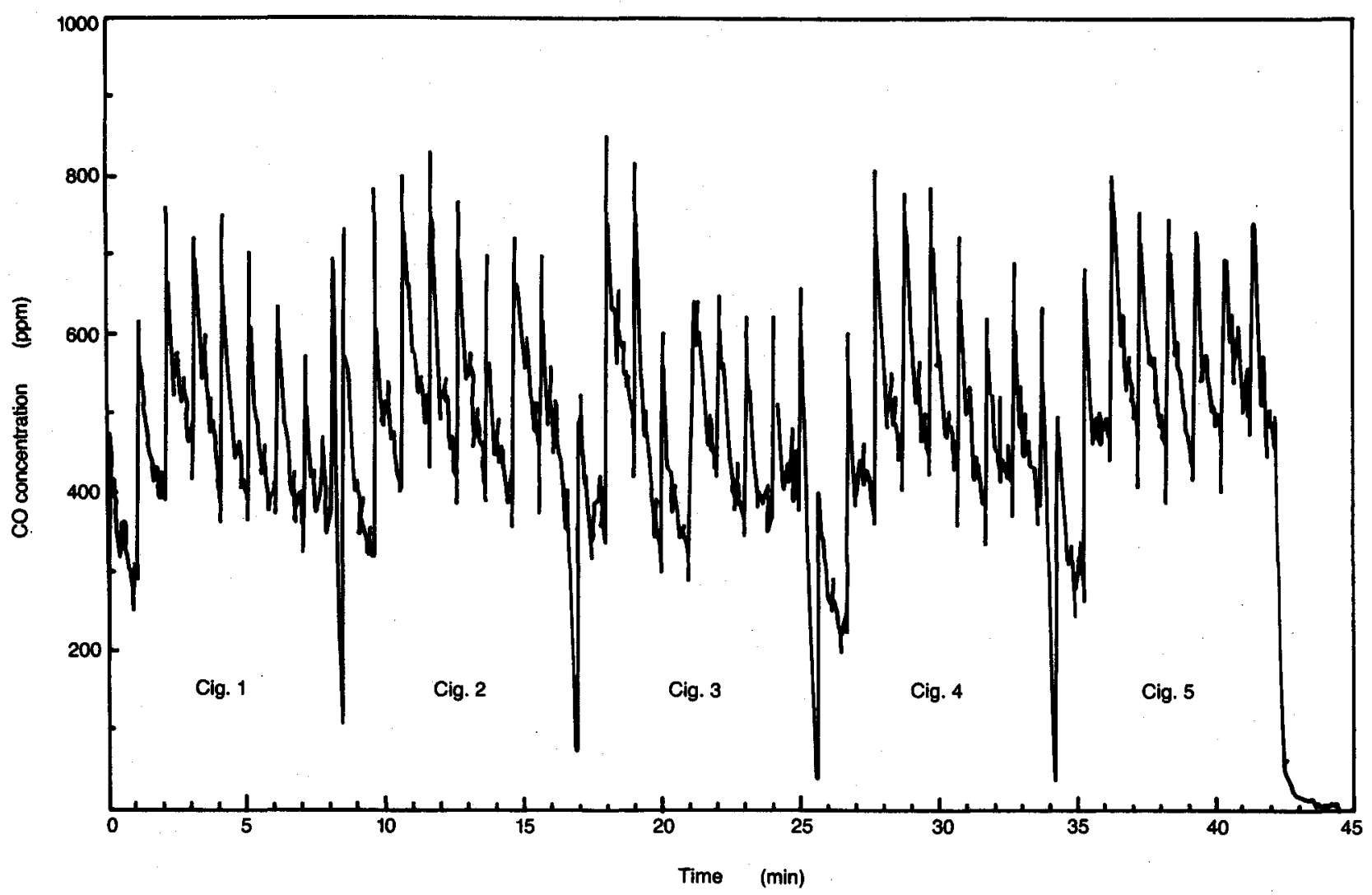

Figure 6.

The proflle of sidestream smoke carbon dioxide.

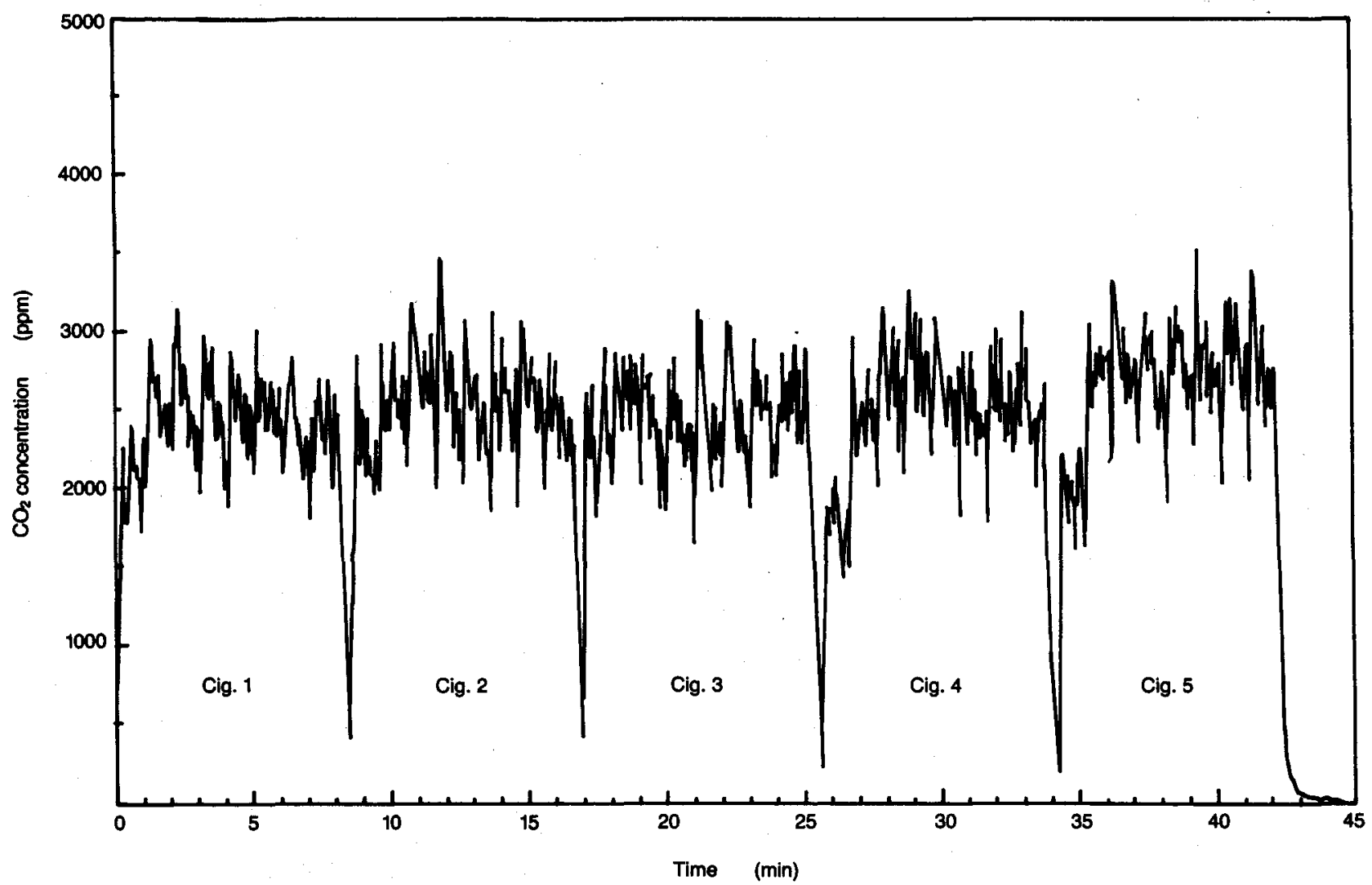


Table 3.

The values of mainstream smoke components measured from clgarettes smoked in the chamber under varlous conditions.

\begin{tabular}{|c|c|c|c|c|c|c|c|c|c|c|}
\hline $\begin{array}{c}\text { Air } \\
\text { flow } \\
\text { rate } \\
(1 / \mathrm{min})\end{array}$ & $\begin{array}{c}\text { Linear } \\
\text { velocity } \\
\text { of air } \\
\text { in chamber } \\
(\mathrm{cm} / \mathrm{s})\end{array}$ & $\begin{array}{l}\text { Distance } \\
\text { between } \\
\text { burning cone } \\
\text { and filter pad } \\
\text { (cm) }\end{array}$ & $\begin{array}{l}\text { Puff } \\
\text { count } \\
\text { (1/cig.) }\end{array}$ & $\begin{array}{c}\text { Total } \\
\text { particulate } \\
\text { matter } \\
\text { (TPM) } \\
(\mathrm{mg} / \mathrm{clg} .)\end{array}$ & $\begin{array}{c}\text { Water } \\
\text { (mg/cig.) }\end{array}$ & $\begin{array}{c}\text { Dry } \\
\text { particulate } \\
\text { matter } \\
\text { (mg/cig.) }\end{array}$ & $\begin{array}{c}\text { Water } \\
\text { content } \\
\text { in TPM } \\
(\%)\end{array}$ & $\begin{array}{l}\text { Nicotine } \\
\text { (mg/cig.) }\end{array}$ & $\begin{array}{c}\text { co } \\
\text { (mg/cig.) }\end{array}$ & $\begin{array}{c}\mathrm{CO}_{2} \\
\text { (mg/cig.) }\end{array}$ \\
\hline 2 & 0.66 & 50 & $\begin{array}{c}9.10 \\
(0.44)\end{array}$ & $\begin{array}{l}29.92 \\
(0.42)\end{array}$ & $\begin{array}{c}6.79 \\
(0.54)\end{array}$ & $\begin{array}{l}23.13 \\
(0.25)\end{array}$ & 22.7 & $\begin{array}{c}1.70 \\
(0.12)\end{array}$ & 23.3 & 62.0 \\
\hline 5 & 1.66 & 50 & $\begin{array}{c}8.52 \\
(0.50)\end{array}$ & $\begin{array}{l}26.22 \\
(0.64)\end{array}$ & $\begin{array}{c}5.20 \\
(0.41)\end{array}$ & $\begin{array}{l}21.02 \\
(0.24)\end{array}$ & 19.8 & $\begin{array}{c}1.48 \\
(0.03)\end{array}$ & 21.8 & 55.9 \\
\hline 8 & 2.65 & 50 & $\begin{array}{c}8.48 \\
(0.50)\end{array}$ & $\begin{array}{l}25.10 \\
(0.51)\end{array}$ & $\begin{array}{c}4.58 \\
(0.26)\end{array}$ & $\begin{array}{l}20.53 \\
(0.52)\end{array}$ & 18.2 & $\begin{array}{c}1.48 \\
(0.05)\end{array}$ & 21.8 & 55.9 \\
\hline 10 & 3.32 & 50 & $\begin{array}{c}8.40 \\
(0.49)\end{array}$ & $\begin{array}{l}24.68 \\
(1.05)\end{array}$ & $\begin{array}{c}4.83 \\
(0.54)\end{array}$ & $\begin{array}{r}19.85 \\
(0.61)\end{array}$ & 19.6 & $\begin{array}{c}1.46 \\
(0.03)\end{array}$ & 21.7 & 55.0 \\
\hline 15 & 4.97 & 50 & $\begin{array}{c}8.40 \\
(0.49)\end{array}$ & $\begin{array}{l}24.00 \\
(0.20)\end{array}$ & $\begin{array}{c}4.08 \\
(0.27)\end{array}$ & $\begin{array}{c}19.92 \\
(0.35)\end{array}$ & 17.0 & 1.44 & 22.0 & 53.0 \\
\hline 10 & 3.32 & 20 & $\begin{array}{c}8.48 \\
(0.50)\end{array}$ & $\begin{array}{l}24.23 \\
(0.53)\end{array}$ & $\begin{array}{c}4.32 \\
(0.18)\end{array}$ & $\begin{array}{l}19.91 \\
(0.43)\end{array}$ & 17.8 & $\begin{array}{c}1.37 \\
(0.05)\end{array}$ & 21.4 & 54.0 \\
\hline 10 & 3.32 & 40 & $\begin{array}{c}8.50 \\
(0.50)\end{array}$ & $\begin{array}{l}25.65 \\
(0.75)\end{array}$ & $\begin{array}{c}5.00 \\
(0.61)\end{array}$ & $\begin{array}{l}20.65 \\
(0.32)\end{array}$ & 19.5 & $\begin{array}{c}1.45 \\
(0.03)\end{array}$ & 21.4 & 53.6 \\
\hline 10 & 3.32 & 50 & $\begin{array}{c}8.40 \\
(0.49)\end{array}$ & $\begin{array}{l}24.68 \\
(1.05)\end{array}$ & $\begin{array}{c}4.83 \\
(0.54)\end{array}$ & $\begin{array}{l}19.85 \\
(0.61)\end{array}$ & 19.5 & $\begin{array}{c}1.46 \\
(0.05)\end{array}$ & 21.7 & 55.0 \\
\hline 10 & 3.32 & 60 & $\begin{array}{c}8.52 \\
(0.49)\end{array}$ & $\begin{array}{l}25.68 \\
(0.68)\end{array}$ & $\begin{array}{c}5.04 \\
(0.30)\end{array}$ & $\begin{array}{l}20.64 \\
(0.48)\end{array}$ & 19.6 & $\begin{array}{c}1.48 \\
(0.05)\end{array}$ & 21.7 & 54.7 \\
\hline Without ch & ber & & $\begin{array}{c}8.32 \\
(0.47)\end{array}$ & $\begin{array}{l}22.70 \\
(0.57)\end{array}$ & $\begin{array}{c}3.66 \\
(0.18)\end{array}$ & $\begin{array}{c}19.04 \\
(0.66)\end{array}$ & 16.1 & $\begin{array}{c}1.42 \\
(0.08)\end{array}$ & 19.9 & 50.7 \\
\hline
\end{tabular}

The numbers in parentheses show the standard deviations.

Table 4.

The values of sidestream smoke components measured from cigarettes smoked in the chamber under various conditions.

\begin{tabular}{|c|c|c|c|c|c|c|c|c|}
\hline $\begin{array}{c}\text { Air } \\
\text { flow } \\
\text { rate } \\
(1 / \mathrm{min})\end{array}$ & $\begin{array}{c}\text { Linear } \\
\text { velocity } \\
\text { of air } \\
\text { in chamber } \\
(\mathrm{cm} / \mathrm{s})\end{array}$ & $\begin{array}{l}\text { Distance } \\
\text { between } \\
\text { burning cone } \\
\text { and filter pad } \\
\text { (cm) }\end{array}$ & $\begin{array}{c}\text { Total } \\
\text { particulate } \\
\text { matter } \\
\text { (mg/cig.) }\end{array}$ & $\begin{array}{c}\text { Water } \\
\text { (mg/cig.) }\end{array}$ & $\begin{array}{c}\text { Dry } \\
\text { particulate } \\
\text { matter } \\
\text { (mg/cig.) }\end{array}$ & $\begin{array}{l}\text { Nicotine } \\
\text { (mg/cig.) }\end{array}$ & $\begin{array}{c}\mathrm{co} \\
\text { (mg/cig.) }\end{array}$ & $\begin{array}{c}\mathrm{CO}_{2} \\
\text { (mg/cig.) }\end{array}$ \\
\hline 2 & 0.66 & 50 & $\begin{array}{c}32.88 \\
(1.97)\end{array}$ & $\begin{array}{c}8.76 \\
(0.65)\end{array}$ & $\begin{array}{c}24.08 \\
(1.36)\end{array}$ & $\begin{array}{c}3.23 \\
(0.27)\end{array}$ & 48.8 & 377.9 \\
\hline 5 & 1.66 & 50 & $\begin{array}{l}23.21 \\
(0.79)\end{array}$ & $\begin{array}{c}2.84 \\
(0.14)\end{array}$ & $\begin{array}{l}20.37 \\
(0.74)\end{array}$ & $\begin{array}{c}2.79 \\
(0.22)\end{array}$ & 51.0 & 380.1 \\
\hline 8 & 2.65 & 50 & $\begin{array}{l}21.17 \\
(1.00)\end{array}$ & $\begin{array}{c}2.12 \\
(0.16)\end{array}$ & $\begin{array}{l}19.05 \\
(0.93)\end{array}$ & $\begin{array}{c}2.53 \\
(0.11)\end{array}$ & 48.2 & 375.4 \\
\hline 10 & 3.32 & 50 & $\begin{array}{l}20.00 \\
(1.05)\end{array}$ & 1.68 & 18.32 & $\begin{array}{c}2.29 \\
(0.09)\end{array}$ & $\begin{array}{c}47.5 \\
(0.75)\end{array}$ & $\begin{array}{c}373.7 \\
(1.3)\end{array}$ \\
\hline 15 & 4.97 & 50 & $\begin{array}{l}18.44 \\
(0.41)\end{array}$ & 1.67 & 16.77 & $\begin{array}{c}1.96 \\
(0.04)\end{array}$ & 48.4 & 372.3 \\
\hline 10 & 3.32 & 20 & $\begin{array}{l}16.77 \\
(0.27)\end{array}$ & 1.50 & 15.27 & $\begin{array}{c}1.38 \\
(0.03)\end{array}$ & 47.3 & 370.7 \\
\hline 10 & 3.32 & 40 & $\begin{array}{c}19.00 \\
(0.89)\end{array}$ & 1.62 & 17.38 & $\begin{array}{c}1.90 \\
(0.07)\end{array}$ & 47.2 & 369.6 \\
\hline 10 & 3.32 & 50 & $\begin{array}{l}20.00 \\
(1.05)\end{array}$ & 1.68 & 18.32 & $\begin{array}{c}2.29 \\
(0.09)\end{array}$ & 47.5 & 353.7 \\
\hline 10 & 3.32 & 60 & $\begin{array}{c}20.97 \\
(0.22)\end{array}$ & 2.22 & 18.75 & $\begin{array}{c}2.16 \\
(0.00)\end{array}$ & 47.6 & 353.2 \\
\hline 10 & 3.32 & 80 & $\begin{array}{c}21.83 \\
(0.59)\end{array}$ & $\begin{array}{c}2.44 \\
(0.13)\end{array}$ & $\begin{array}{c}19.39 \\
(0.69)\end{array}$ & $\begin{array}{c}2.64 \\
(0.09)\end{array}$ & - & - \\
\hline
\end{tabular}

The numbers in parentheses show the standard deviation. 
Table 5.

The values of sldestream smoke components measured per clgarette.

\begin{tabular}{c|c|c|c|c}
\hline $\begin{array}{c}\text { Number of cigarettes } \\
\text { per filter pad } \\
\text { (cig./ filter pad) }\end{array}$ & $\begin{array}{c}\text { Total particulate matter } \\
\text { (mg/cig.) }\end{array}$ & $\begin{array}{c}\text { Water } \\
\text { (mg/cig.) }\end{array}$ & $\begin{array}{c}\text { Dry particulate matter } \\
\text { (mg/cig.) }\end{array}$ & $\begin{array}{c}\text { Nicotine } \\
\text { (mg/cig.) }\end{array}$ \\
\hline 2 & 19.05 & 1.13 & 17.92 & 2.24 \\
& $(0.55)$ & $(0.28)$ & $(0.27)$ & $(0.02)$ \\
4 & 19.76 & 1.48 & 18.28 & 2.22 \\
& $(0.80)$ & $(0.01)$ & $(0.80)$ & $(0.03)$ \\
& 20.00 & 1.68 & 18.32 & 2.29 \\
6 & $(1.05)$ & & & $(0.09)$ \\
& 20.02 & 1.79 & 18.23 & 2.26 \\
8 & $(0.45)$ & $(0.24)$ & $(0.21)$ & $(0.06)$ \\
& 19.88 & 1.49 & 18.39 & 2.22 \\
\hline
\end{tabular}

Air flow rate: $10 \mathrm{I} / \mathrm{min}$, distance between burning cone and filter pad : $50 \mathrm{~cm}$. The numbers in parentheses show the standard deviation.

\section{Measured Values of \\ Mainstream Smoke Components}

The measured values of mainstream smoke components with and without the chamber are summarized in $\mathrm{Ta}$ ble 3. The smoke components, particularly water content in the particulate matter per cigarette, increased with decreasing air flow rate. This indicates a considerable change in burning characteristics due to the poor ventilation in the chamber. The same results have been reported by KLus and KunN (8) who used a small chamber. As shown in Table 3, however, increasing the air flow rate through the chamber reduced the influence of the chamber on the mainstream smoke components.

\section{Measured Values of \\ Sidestream Smoke Components}

Levels of the sidestream smoke components under various conditions are summarized in Table 4. The level of sidestream smoke particulate matter increased as the air flow rate through the chamber decreased. This is thought to be due not only to the change in burning characteristics because of poor ventilation but also to the enhancement of condensation and coagulation to form particles. On the other hand, a large air flow rate promotes revaporization of volatile substances in the particulate matter trapped on the filter pad during the sidestream smoke collection (9). As shown in Table 5, however, the increase in the number of cigarettes smoked hardly affected the amount of particulate matter per cigarette at the flow rate of $10 \mathrm{l} / \mathrm{min}$. This leads to the conclusion that revaporization of particulate matter on the filter is negligible for the determination of sidestream smoke at the flow rate of $10 \mathrm{l} / \mathrm{min}$. By increasing the distance between the burning cone and the filter pad, the amount of particulate matter in- creased, while the amounts of $\mathrm{CO}$ and $\mathrm{CO}_{2}$ remained constant (Table 4). The data in Table 4 show that $50 \mathrm{~cm}$ is the best distance between the burning cone and the filter pad, and that the optimum air flow rate is $101 / \mathrm{min}$. Under these conditions, the standard deviation of the sidestream smoke components was comparable to that of mainstream smoke components.

\section{Profile of Carbon Oxides in Sidestream Smoke}

Figures 5 and 6, respectively, show typical profiles for $\mathrm{CO}$ and $\mathrm{CO}_{2}$ released from the burning cone of five cigarettes smoked successively. Each profile peak was obtained during puffing. The change in the concentration of $\mathrm{CO}$ during the puff was larger than that of $\mathrm{CO}_{2}$. The large increase in the concentration of carbon oxides suggests that a proportion of $\mathrm{CO}$ and $\mathrm{CO}_{2}$ formed during a puff is released from the burning cone to the atmosphere.

\section{Sidestream Smoke in Environment}

The weight of sidestream smoke particles generated under standard smoking conditions was determined by a piezoelectric balance mass monitor (10) in a $27 \mathrm{~m}^{3}$ airtight room. The value was $6 \mathrm{mg} / \mathrm{cig}$., corresponding to only $40 \%$ of the value measured with the cylindrical chamber under the above-mentioned conditions. The weight of $\mathrm{CO}$ of sidestream smoke per cigarette in the same room was $43 \mathrm{mg}$ which corresponded to more than $90 \%$ of the value measured with the cylindrical chamber. Consequently, an estimation of the concentration of smoke particles in a room is not possible from the chamber measurement, but an estimation of $\mathrm{CO}$ is acceptable. 


\section{REFERENCES}

1. Neurath, G., und H. Ehmke: Apparatur zur Untersuchung des Nebenstromrauches; Beitr. Tabakforsch. 2 (1964) 117-121.

2. Neurath, G., H. Ehmke und H. Schneemann: Über

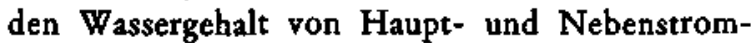
rauch; Beitr. Tabakforsch. 3 (1966) 351-357.

3. Rickert, W. S., J. C. Robinson and N. Collishaw: Yields of tar, nicotine and carbon monoxide in the sidestream smoke from 15 brands of Canadian cigarettes; Am. J. Public Health 74 (1984) 228-231.

4. Johnson, W. R., R. W. Hale, J. W. Nedlock, H. J. Grubbs and D. H. Powell: The distribution of products between mainstream and sidestream smoke; Tob. Sci. 17 (1973) 141-144.

5. Harris, J. L., and L. E. Hayes: A 20-port sidestream smoke collection system; presented at the 32nd Tob. Chem. Res. Conf., Montreal, Canada, 1978.

6. Browne, C. L., C. H. Keith and R. E. Allen: The effect of filter ventilation on the yield and composition of mainstream and sidestream smokes; Beitr. Tabakforsch. Int. 10 (1980) 81-90.

7. Repace, J. L., and A. H. Lowrey: Indoor air pollution, tobacco smoke and public health; Science 208 (1980) 464-472.

8. Klus, $H$., and $H$. Kuhn: Verteilung verschiedener Tabakrauchbestandteile auf Haupt- und Nebenstromrauch (Eine Úbersicht); Beitr. Tabakforsch. Int. 11 (1982) 229-265.
9. Ishizu, Y., and K. Ohta: Estimation of the weight of smoke particles generated from a cigarette; Trans. Soc. Heat. Air-cond. Sanit. Eng. Jpn. 15 (1981) 89-94.

10. Sem, J. G., K. Tsurubayashi and K. Homma: Performance of the piezoelectric respirable aerosol sensor; Am. Ind. Hyg. Assoc. J. 38 (1977) 580588.

\section{Acknowledgement}

The authors would like to express their gratitude to Dr. T. Yamamoto for bis belpful advice in the course of this study.

Autbors'address:

Central Researcb Institute,

Japan Tobacco Inc., 6-2 Umegaoka, Midori-ku, Yokobama, Kanagaroa, 227, Japan. 